\title{
Die NG Kerk se profetiese stem teenoor die Suid-Afrikaanse owerheid in die dekade na 1994 - vanuit kerklike perspektief en op kerklike wyse
}

\author{
Strauss, Piet \\ Universiteit van die Vrystaat \\ straussp@ufs.ac.za
}

\begin{abstract}
The prophetic voice of the Dutch Reformed Church to the South African Government in the decade after 1994

When referring to the viewpoints of the Dutch Reformed Church as a whole, one should look for the decisions of its general synod. In trying to be a church and a prophet, this General Synod should speak out according to the Bible and in the way of a church or an institution of faith.

The Dutch Reformed Church indeed spoke as a prophet to the government in the decade after 1994. However, it was done with a certain reluctance and not from an overall perspective. Two main factors contributed to this. There is a difference in worldview between this church and the government. The Dutch Reformed Church had the experience that a little came of its efforts.

In the meantime the Dutch Reformed Church remains convinced that it should promote the kingdom of God in South Africa as a church and through its individual members.
\end{abstract}

Key words

Dutch Reformed Church; prophet; government; institution of faith 


\section{Probleemstelling}

Sedert die ontstaan van sy eerste Algemene Sinode in 1962, berus bindende besluite oor algemene sake in die NG Kerk, sake soos "beleid"1 op punte van gemeenskaplike belang, by die Algemene Sinode (vgl NGKO 1962:9; NGKO 1994:9; NGKO 1998:15; vir 'n soortgelyke interpretasie kyk NGK 1994:439). Hierdie werkswyse word in sy Kerkorde artikel 43 (NGKO 1962:9 artikel 43; NGKO 1994:9 artikel 43; NGKO 1998:15 artikel 43; NGKO 2002:11 artikel 43) gereël. Dit beteken dat die NG Kerk in sy geheel as 'n sinodale kerkverband deur sy Algemene Sinode met die staatsowerheid praat. Die gesagvolle stem van die NG Kerk in dié geval is nie die moderator of voorsitter van die Algemene Sinode as die "pous", 'n kommissie van hierdie sinode of enige ander NG Kerkvergadering nie, maar die Algemene Sinode. 'n Besluit of uitspraak namens die NG Kerk in sy geheel word deur sy Algemene Sinode geneem of gefinaliseer. Tensy die moderator of kommissie of span so 'n opdrag met volmag vir uitvoering, van die Algemene Sinode self ontvang (NGKO 2013:5).

As dit in hierdie stuk om die profetiese stem van de NG Kerk teenoor die Suid-Afrikaanse owerheid gaan, gaan dit om standpunte met die sanksie van sy Algemene Sinode. Die uitdrukking "die NG Kerk se profetiese stem", soos deur die NG Kerk self verstaan, beperk hierdie stem tot die uitsprake van die Algemene Sinode.

Volgens die NGKO pas 'n ander bepaling hierby. NGKO 1994, NGKO 1998 en NGKO 2002, die kerkordes wat die optrede van die Algemene Sinode in die dekade na 1994 moes reël, bepaal dat die profetiese stem van die NG Kerk handel oor "kerklike sake en wel op 'n kerklike wyse ..." (NGKO 1994:5) of "sake vanuit kerklike perspektief, in die lig van die woord van God en op kerklike wyse” (NGKO 1998:9; NGKO 2002:11). Hoewel hierdie twee artikels die saak verskillend omskryf, lei dit nie tot duidelike verskille in die praktyk nie. Daarop kom ons terug. Genoeg om hier te sê dat albei trag om 'n tipies kerklike stem as die profetiese stem van die NG Kerk aan te dui.

1 Die woordjie "beleid" met sy nie-kerklike konnotasies word verduidelikend versag met die byvoeging van die byvoeglike naamwoord "kerklike", NGKO 1994:9; NGKO 1998:15. Dit stem dus ooreen met die gebruikswyse van woorde soos "kerkorde" en "kerkvergadering". 
Die jaar 1994 is die jaar waarin Suid-Afrika oorgaan van 'n beperkte demokrasie of stemreg soos gereël deur die Grondwet van 1961 na algemene stemreg: stemreg vir geregistreerde burgers of volwassenes bo 18, afgesien van ras, velkleur of geslag. 'n Saak gereël deur die Interim Grondwet van 1993 wat in 1996 deur die huidige Suid-Afrikaanse Grondwet vervang is (Kleyn en Viljoen 1999:241-243,259,270). De Villiers noem dit "veel meer" as 'n nuwe staatkundige bedeling. Die veranderinge in Suid-Afrika waarvan "1994" die simbool is, het tot "omvattende en radikale verskuiwinge" gelei en "min lewensterreine onaangetas" gelaat: dit het "n (totale) nuwe SuidAfrika” ingelui (De Villiers 1999:15). 'n Suid-Afrika met 'n Handves van Regte in hoofstuk 2 van sy grondwet wat die reg in die gemeenskap bepaal en die kernmaatstaf is waarmee die land se howe sake bereg of uitsprake makk. Boonop het die Grondwet van 1996 soos geïnterpreteer en toegepas deur die howe hoër regsgesag as die besluite van die parlement. Dit is 'n grondwet vir 'n nie-rassige, nie-seksistiese, liberale demokrasie met die klem op die vryheid van die indiwidu. 'n Demokratiese grondwet gebou op openheid, demokrasie, vryheid, gelykheid en menswaardigheid as waardes wat 'n nuwe waardestelsel in die gemeenskap skep (Kleyn en Viljoen 1999:241-244, 258-261; Stone 2014:154-155).

Dit is ou nuus dat 'n nuwe ANC-regering in 1994, na die eerste algemene verkiesing in Suid-Afrika, by 'n gediskrediteerde Nasionale Partybewind oorgeneem het. 'n Nasionale Bewind wat na sy bewindsaanvaarding in 1948 deurentyd simpatiek na die stem van die NG Kerk geluister het (Botes 2012:364).

Hierdie verskuiwings het veroorsaak dat die leefwêreld waarin die NG Kerk sy profetiese stem moes laat hoor, na 1994 ingrypend verander het. Die gesagvolle stem van die NG Kerk in die gemeenskap asook die van sy regeervergaderings (kerkraad, ring, sinode en algemene sinode, NGKO 1994:5 artikel 18) onder sy gemeentelede, het sigbaar afgeneem (Botes 2012:366; De Villiers 1999:19, 24-27).

Die vraag wat hierdie artikel vra, is: wat was die inhoud en effek van die profetiese stem van die NG Kerk op die staatsowerheid in Suid-Afrika in die dekade na 1994? Anders gestel: wat was die invloed van die NG Kerk op die geestelike rigting en onderliggende waardestelsel van die maatreëls waartoe hierdie owerheid homself verbind het? Hierdie saak is immers ook 
van kerklike belang of 'n kwessie wat die Bybelsbepaalde geloofsterrein van die NG Kerk kruis. Steeds op hierdie lyn: wat was die insette en invloed van die NG Kerk op die maatreëls van die owerheid wat die publieke regsbelang van sy lidmate raak? Die behartiging van hierdie belang is immers die kern van die owerheidstaak as die regering van die dag (Fowler 1988:11; Stone 2014:175).

Die dekade na 1994 lê reeds lank genoeg terug om te beweer dat daar tans vanuit 'n veranderde situasie en vanaf 'n groter afstand minder gevoelig na die NG Kerk en die staatsowerheid tot ongeveer 2004 gekyk kan word.

In hierdie artikel word 'n kerkhistoriese greep op die inhoud van die NG Kerk se profetiese stem in die dekade na 1994 voorafgegaan deur die vasstelling van die betekenis van NGKO artikel 21. Artikel 21 bepaal die sake waarmee kerkvergaderings besig is of waarby hierdie vergaderings as vergaderings van die kerk, hulle moet hou. NGKO 1994 artikel 21 soos gewysig deur NGKO 1998 artikel 21 is op sigwaarde 'n Skrifgeoriënteerde maatstaf vir tipies kerklike besluite. In sy kern kom artikel 21 daarop neer dat kerkvergaderinge (alle ${ }^{2}$ ) sake vanuit kerklike perspektief, in die lig van die Woord van God en op 'n kerklike wyse hanteer. Hierdie maatstaf rig die antwoorde op die volgende vrae: vanuit watter perspektief praat die kerk as kerk, wanneer moet hy praat en hoe doen hy dit geloofwaardig (Strauss 2010:57)?

\section{Sake vanuit kerklike perspektief en op kerklike wyse}

Hommes is waarskynlik reg as hy beweer dat die interpretasie van kerklike sake of die sake waaroor die kerk praat, in die situasie dikwels die "stempel van haar tijd ... op het voorhoofd" dra (Hommes sa: 5). Hierdie stempel word bepaal deur die geestelike omgewing waarin lidmate hulle bevind, waar kerklike hulp volgens hulle nodig is en waar die stem van die kerk, wat hulle betref, gehoor moet word. 'n Kerklike hupstootjie vir hulle niekerklike optrede is vir sommige dieselfde as 'n Bybelse wettiging daarvan

2 Die feit dat die sake van NGKO artikel 21 nie van 'n omskrywende byvoeglike naamwoord voorsien is nie, dui daarop dat hierdie sake nie beperk word nie. Die tipiese van die kerk in artikel 21 lê dus nie in die sake nie, maar in die kyk op die sake: die kerklike perspektief en kerklike wyse. 
(Spoelstra 1989:181). Daarby, as die kerk nie hulle politieke mening steun nie, versuim hy - dit is volgens Kuitert die klag van "linkse" groepe - sy Bybelse plig deur sy afsydigheid aan die nood of onreg van dié mense wat deur hierdie groepe uitgesonder word (Kuitert 1988:155).

Dit is so dat die kerk se profetiese stem ook moet rekening hou met die billike of redelike verstaan deur lidmate van die taak van die kerk as 'n Bybelse geloofsgemeenskap. Dat die kerk vanuit die Woord van God as sy geestelike instrument of snydende swaard so moet praat dat hoorders daarin sonder moeite die stem van God herken. Dat die profetiese stem van die kerk die wil van God moet oordra om gesagvol en geloofwaardig te wees. 'n Geloofwaardigheid wat bou of rus op die oortuiging dat die kerklike boodskap spreekwoordelik "van God" is (vgl I Kor 3 vir die kerken sy boodskap - as die saailand, gebou en tempel van God; die aanhef van die boeke van die Ou Testamentiese profete en die briewe van Paulus; en Strauss 1994:590-591).

NGKO 1998 artikel 21 praat in sy hersiening van NGKO 1994 se "kerklike sake en wel op 'n kerklike wyse" van kerkvergaderinge wat "sake vanuit kerklike perspektief, in die lig van die Woord van God en op kerklike wyse ... behandel" (NGKO 1998:9). Dit gaan vir NGKO 1998 dus om 'n beter formulering van NGKO 1994 artikel 21 en nie die skrapping daarvan nie. Daarby open NGKO 1998 die moontlikheid van 'n kerklike invalshoek én 'n eie kerklike styl vir die NG Kerk as 'n geloofsgemeenskap wat gerig word deur die Bybel of “... die lig van die Woord”.

Dit beteken dat die kerk deur sy verstaan van Skrifbeginsels gelei moet word en nie noodwendig direk deur Bybeltekste nie. Die inhoud van 'n kerklike profesie moet breedweg Bybelsbepaald wees om 'n uitdrukking van God se wil te wees én pas by die aard van die kerk as 'n gemeenskap wat rondom die Christelike geloof vorm. Kerklike profesieë is handelinge wat deur die geloof gerig word en die lig van die Bybel kan deurstaan. Handelinge wat gereflekteer word in die geloofsbelydenis van God Drie-enig deur lidmate by die bevestiging van hulle lidmaatskap.

Geloofhandelinge wat veronderstel dat die kerk die reg het om sy geloof uit te druk op grond van sy verstaan van die Bybel. Dat die kerk die reg het om die implikasies van sy geloof op grond van die Bybel te verreken en dat sy terrein van kompetensie die Christelike geloof en die Bybel 
as - primêr - 'n normatiewe geloofsboek is (Kock 1975:142-144; Strauss 1994:591; 2010:60; 2013:89-90). 'n Reg wat as artikel 15 in die Handves van Regte van die Grondwet van Suid-Afrika (1996) opgeneem is as die reg op godsdiensvryheid (Kleyn en Viljoen 1998:269; vgl NGKO 2013:1 artikel $\left.3.3^{3}\right)$.

Die tradisionele kerkordebepaling vir die sake waaroor kerke met 'n Nederlandse gereformeerde band praat en besluit, gaan terug tot op die Provinsiale Sinode van Dordrecht in 1574 in Nederland. Hierdie vergadering vereis in sy vyfde artikel dat kerkvergaderings alleen sake wat "Kerkckelijck" is, hanteer (Biesterveld en Kuyper 1905:63). In 1581 neem die Nasionale Sinode van Middelburg die sedertdien geykte "kerkckelijke zaken" op "kerkckelijke wijse" in artikel 21 van sy kerkorde op (Biesterveld en Kuyper 1905:147). Hiermee volg die Gereformeerde Kerk in Nederland in die sestiende eeu die spore van sy geestelike vader, Johannes Calvyn (1509-1564). Calvyn onderskei die "geestelijke regering" van die kerk (die geestelike "politie" van artikel 30 van die Nederlandse Geloofsbelydenis (NGB), Polman sa:7) van die "burgerlijke" regering van die staatsowerheid (Sizoo III sa:235-238). Daarmee stuit die Hervormer van Genève op die eie aard van die kerk se hantering van sake.

Die uitdrukking "kerklike sake op kerklike wyse" kom dus vir meer as vier eeue al in gereformeerde kerkordes met 'n Nederlandse band voor. Tog verskil hulle onderling oor die verstaan hiervan. Hierdie verskille handel nie oor die "kerklike wyse" nie, maar die "kerklike sake".

\section{Kerklike sake teenoor kerklike perspektief}

Die begrip "kerklike sake" op sigself dui op 'n ruimtelike afgrensing of kompartementalisering van 'n reeks gelyste sake wat kerkvergaderings moet hanteer. Hierdie kompartementalisering word weerspieël in die kommentaar van sommige vroeëre gereformeerde kerkregtelikes. Genoemde Sinode van Dordrecht (1574) praat van voorafomskrewe, gelyste sake op die kerklike agenda wat voortdurend òf kerklik òf gedeeltelik

3 NGKO 2013:1 artikel 3.3 reël hierdie interne, wetlik gewaarborgde kompetensiesfeer van die NG Kerk met "Die NG Kerk reël haar eie interne orde op grond van haar onvervreembare roeping en interne bevoegdheid as kerk van Jesus Christus en ook op grond van haar reg tot vryheid van godsdiens". 
kerklik en polities van aard is. Onder laasgenoemde sou huweliksluiting byvoorbeeld ressorteer. Die Nasionale Sinode van Dordrecht van 1578 neem hierdie onderskeidings byna netso oor (Biesterveld en Kuyper 1905:63, 102). Die Sinodes van die Gereformeerde Kerke in Suid-Afrika (GKSA) van 1916 en 1942 volg dieselfde lyn. Hulle noem huwelikswetgewing, onderwys, die versorging van armes, onsedelikheid en die aflê van die eed gemengde sake. Maatskaplike, staatkundige en "streng" wetenskaplike kwessies boek hulle permanent onder nie-kerklike sake of sake wat nooit op 'n kerklike agenda moet beland nie. Dat hierdie onderskeidings relatief is en in die kerklike praktyk anders kan uitdraai, word bevestig deur die bykomende reëling dat elke vergadering vir homself moet uitmaak watter sake onder watter hofie tuiskom (Spoelstra 1989:181-182). Hierdie GKSASinodes toon dus 'n "natuurlike aanvoeling" dat kompartementalisering nie die probleem van tipiese kerklike optrede of die vraag waaroor kerklike profesie alles kan gaan, in alle gevalle oplos nie. Die verbande waarin sake hulle voordoen kan 'n konstante lysie van kerklike sake gou waardeloos makk. "Kerklike sake" kan nie vir alle tye en onder alle omstandighede in afgegrensde kategorieë ingedruk word nie.

Eertydse gereformeerde kerkregtelikes soos FL Rutgers, H Bouwman en J Jansen sluit hulle by die onderskeiding van konstante kerklike, gemengde en nie-kerklike sake aan. Volgens hulle - hulle gee ook praktiese voorbeelde kan sake onder die eerste twee hofies op die agenda van die kerk beland, maar nie die sake onder die derde hofie nie (Rutgers 1921:254; Bouwman 1985:30-31; Jansen 1952:143).

'n Uitsondering in hierdie opsig is D Nauta, 'n kanonikus uit 'n volgende geslag. Nauta is 'n medewerker aan die nuwe Kerkorde van die Gereformeerde Kerke in Nederland (GKN-KO) van 1959 (Nauta 1971:37). In sy kommentaar op GKN-KO 1959 wat "kerklijke zaken" as die enigste sake vir kerkvergaderings reserveer (Nauta 1971:126 kom met 'n woordelikse GKN-KO artikel 29), werk Nauta met die Christelik- wysgerige en Bybelsverantwoorde gedagte dat die skepping van God 'n eenheid in 'n verskeidenheid vorm waarin alles met alles saamhang of alles met alles vervleg is. Die funksionering van die mens in die twee-eenheid van siel en liggaam of as 'n eenheid met verskillende gawes en moontlikhede, is 'n voorbeeld hiervan. Enige geloofs-, liefdes- of regsaksie (alle menslike aksies of lewenskringe word deur 'n bepaalde aspek van die skepping gelei 
of gekwalifiseer) funksioneer tegelykertyd in alle aspekte van die lewe. Daarom kan enige mense-aksie, of dit 'n huweliks-, staats-, ekonomiese of wetenskaplike aksie is, kerklike geloofsbelang kruis of 'n kerklike aspek ontwikkel - sonder om self deur die geloof gekwalifiseerd te raak. Die eie aard van alle aspekte van die lewe bestaan oorspronklik en selfstandig, maar vervleg met mekaar. Geloof bly geloof, liefde in verhoudinge liefde en reg (Nauta 1971:127). Daarby bestaan daar egter ook vervlegte begrippe soos Skrifgetrouheid, die reg op geloofsvryheid, geloofstaal en kerklike simbole waarin geloof in sy funksionering die kern van respektiewelik die liefde, die reg en taal of simboliese betekening in diens neem as beginsels of vertrekpunte om in die volle lewe te funksioneer (Strauss 2010:2).

'n Kerklike perspektief op sake beteken dat die kerk alle sake vanuit die hoek van die Christelike geloof of Christelike geloofsbelang soos verwoord in die Heilige Skrif, benader - dit is sy profetiese roeping. Boonop spruit alle sake onder die son vanuit 'n sekere waardestelsel of vertoon dit implikasies of kenmerke daarvan. 'n Waardestelsel wat nie noodwendig Bybelsbegrond is nie, maar waarop die lig van die Woord wat die hele lewe vanuit sy grondwaarhede of -plan vir die lewe belig, ook val (Strauss 1994:590-591). Die aanduiding van die kerklike karakter van sake lê dus nie in 'n ruimtelike afgrensing van die sake wat hanteer word nie, maar in die onderskeiding van 'n kerklike invalshoek (of Bybelse geloofsbelang) wat gebruik word. Kerklike sake bestaan nie uit 'n staande lys van sake nie, maar word dinamies geïdentifiseer vanuit die hoek van die BybelsChristelike geloof of kerklike geloofsbelang (Strauss 2010:59-60).

Nauta gee voorbeelde van wat hy met 'n saak wat "een of ander kerklijke aspect" ontwikkel, bedoel: geld as 'n betaalmiddel kan kerklike finansies word, argiteksplanne en die bouwerk van messelaars kan tot pastorieë lei en die lewensbeskoulike kante van sosio-politieke sake kan kerkeie geloofsake as profetiese kwessies weerspreek (Nauta 1971:127).

Gevolglik gaan dit hier om die differensiëring van die eie aard en tipiese aktiwiteite van samehangende lewenskringe, nie om 'n statiese, ruimtelike kompartementalisering of isolering daarvan teenoor mekaar nie. 'n Konsekwente Christen se deelname aan 'n verskeidenheid samelewingskringe moet vanuit die kwalifiseringsfunksie van elke kring aangevul en nie geopponeer word nie. Hy of sy moet die lewe as 'n eenheid 
in 'n verskeidenheid beleef en nie as innerlik teenstrydig nie (vgl Rom 12:12). Kerk en staat kan in diens van die drie-enige God harmonieer en mekaar aanvul met die kerk vanuit sy geloofs- en die staat vanuit sy regshoek. As die beeld van die menslike liggaam wat in I Korintiërs 12 vir die gemeente gebruik word, op die samelewing toegepas word, kan die kerk die oog en die staat die oor - albei in diens van God - wees: elkeen met respek vir die ander een se tipiese taak.

Vir die NG Kerk moet die profetiese uitsprake van sy vergaderings oor die sake wat behandel word "vanuit kerklike perspektief, in die lig van die Woord van God en op kerklike wyse" wees. Dieselfde riglyne kan gebruik word aan die hand van NGKO 1994 artikel 21 wat voor 1998 kerklike sake op 'n kerklike wyse wou beoefen. 'n Aantal sake waaroor die NG Kerk die Suid-Afrikaanse staatsowerheid in die dekade na 1994 "profeties" benader het, sowel as die effek daarvan, word dus ondersoek. 'n Eie evaluering van dié profetiese stem word ook gegee. Die sake waaraan aandag gegee word, is die nuwe staatkundige bedeling of liberale demokrasie, die heropbou en ontwikkelingsprogram van die nuwe regering (HOP), die herverdeling van grond in Suid-Afrika en misdaad en korrupsie. Hierdie profesieë van die NG Kerk word primêr aan die hand van sy eie Kerkorde artikel 21 (NGKO 1994, NGKO 1998 en NGKO 2002) beoordeel. Dit gaan oor sake wat die belang van die Christelike geloof kruis en daarom vanuit - hopelik Skriftuurlike waardestelsel benader word.

\section{Die nuwe liberale demokrasie}

By die Algemene Sinode in Oktober 1994 - net meer as 5 maande na die oorname van die ANC-bewind in April - vra en verkry die Tydelike Kommissie vir Leer en Aktuele Sake (TKLAS) 'n opdrag van die vergadering dat hy "met dringende spoed" aan die gemeentes leiding gee oor hul benadering van die staatkundige oorgangstyd in Suid-Afrika. Hy moet kyk na insig in die "ingrypende en ingewikkelde proses" en aan 'n groter "verbeeldingryker en gemotiveerde aandeel" van lidmate aan vernuwings-, versoenings- en heropboupogings in die land (NGK 1994:501).

Dat hierdie "dringende spoed" kerklik gesproke egter nie op 'n groot haas dui nie, blyk uit die feit dat die stuk wat hieruit gebore word, eers by die volgende Algemene Sinode, in 1998, ter tafel kom. Daarby gaan dit 
in die stuk nie om 'n profeties-kritiese begeleiding van die ingrypende en ingewikkelde oorgangsproses nie, maar sake waaraan lidmate aandag moet gee in hulle aandeel aan 'n herboude en versoende nuwe Suid-Afrika.

Die NG Kerk is nie soos voor 1994 'n voorloper in die oorgang nie, maar probeer nou van die kant af aanvaarbare insette lewer. Reeds die verwoording van die opdrag dra 'n gees van "ons het nie langer die inisiatief nie, maar wil aanvaarbaar wees en meewerk".

Die staande Kommissie vir Leer en Aktuele Sake (AKLAS) se finale stuk sien die lig met min omstrede kwessies en verskeie konsensuspunte onder NG-lidmate wat na 1994 in Suid-Afrika sou aanbly (NGK 1998:68-78).

Onder die "Die oorgang na 'n nuwe Suid-Afrika" wys die Kommissie op 'n omvattende "transformasie" van die Suid-Afrikaanse samelewing wat die gevolge van apartheid moet uitwis en 'n demokratiese, nie-rassige, nie-seksistiese toekoms moet bou. 'n Toekoms met 'n eie waardestelsel wat vanuit hierdie hoek op die agenda van die NG Kerk beland. Hierdie toekoms raak die skep van werk, behuising, water, sanitasie, energie, telekommunikasie, vervoer, voeding, gesondheidsorg, welsynsdienste en die hervorming van grond. Daarby kom opleiding en onderwys vir almal, gelykheid in die ekonomie ten opsigte eienaarskap, werk en vaardighede, die uitskakeling van 'n wanbalans in die "magsposisie van werkgewers en werknemers" en die demokratisering van die staat en die samelewing. Die toekoms is 'n nie-rassige, liberale demokrasie gerig op gelykheid, die uitskakeling van die onreg van die verlede en 'n werkbare versoening. By 'n laaste punt onder die oorgang wys die Kommissie op die verdieping van die morele krisis in die samelewing.

Onder 'n tweede opskrif kyk AKLAS na die gevolge van die oorgang vir die NG Kerk. Die Kommissie wys heel eerste op die "oorwegend negatiewe houding" by die meerderheid lidmate teenoor die, vir hulle, nuwe SuidAfrika. Dié houding stimuleer 'n onttrekking aan die openbare lewe, 'n beklemtoning van die regte van die Afrikaner, 'n swakker band met die NG Kerk, 'n worsteling met die gereformeerde identiteit van die NG Kerk én 'n morele en leerstellige onsekerheid by lidmate. Laasgenoemde spruit uit hulle vervreemding van die sedelike en geloofsleer van die verlede. 'n Leer wat nie die komplekse oorgang kon verhoed nie. 
Die regte benadering van die oorgang koppel AKLAS aan vier punte wat hy op die NG Kerk rig. Eerstens moet hierdie Kerk duidelikheid kry oor sy rol as kerk in die nuwe Suid-Afrika. Tweedens moet lidmate geïnspireer word om hulle Christelike roeping in die land na te kom. Emigrasie moet verbind word aan die oortuiging dat die Here hulle koninkryksroeping in Suid-Afrika vir 'n roeping in 'n ander land verruil. Dat die Here hulle skuif. Emigrasie is noodsaak: werk is onbekombaar in Suid-Afrika en emigrasie die laaste uitweg. Lidmate leef immers om koninkryksdiens in kerk en samelewing te verrig. Derdens moet die NG Kerk sy lidmate oortuig om diensbaar te wees in die liberale demokrasie. Hulle kan binne die vryheid wat die Grondwet bied, gestalte te gee aan 'n outentieke Christelike lewenstyl, Christelik-morele deugde, diensvaardigheid en diens, die bevordering van versoening, hulp aan swakkes en die bestryding van die morele krisis op alle vlakke. Vierdens moet die NG Kerk op 'n nuwe manier as profeet sy openbare getuienis in Suid-Afrika lewer. Hy moet streef na 'n konsensus in die NG Kerk en van die NG Kerk met ander kerke oor openbare kwessies en bereid wees om 'n openbare debat daaroor te voer.

'n Eerste reaksie op hierdie stuk van ALKAS is dat, in vergelyking met kritiek op apartheid in Kerk en Samelewing 1986 en 1990, die nuwe Suid-Afrika na sy eerste vier jaar lig daarvan afkom. 'n Deel van die Bybels-kerklike profesie van die NG Kerk moet wees om die onderliggende waardestelsel van alle verskynsels - sonder aansiens des persoons - aan te spreek. Die openbare waardes waarop die nuwe land gedryf word, word genoem maar sonder 'n kritiese ontleding. Die manier waarop die stuk probleme in Suid-Afrika aanstip, skep die indruk asof hierdie probleme alles uit die vorige bedeling as die oorsaak daarvan kom. Dit moet nou opgelos word omdat apartheid dood is en die liberale demokrasie leef. ${ }^{4}$ Later, na byna 'n kwarteeu van 'n liberale demokrasie is water, sanitasie, voeding, gesondheidsorg, werkverskaffing, grondhervorming en staatswelsyn egter steeds 'n probleem.

In sy profetiese stem moes die NG Kerk, om geloofwaardig te wees, die probleme vir die oorgang vanuit'n Bybelse waardestelsel ontleed het om by 'n begronde aanpak daarvan uit te kom. 'n Meer omvattende en realistiese

4 JA Heyns praat by geleentheid van die anti-apartheidsmite dat alle probleme in SuidAfrika opgelos sal word as daar van apartheid ontsale geraak word, Williams 2006:327. 
aanpak van probleme sou meer geloofwaardig en meer positief appelleer op negatiewe NGK-lidmate. Die stuk praat van profetiese kritiek op negatiewe lidmate wat hyself - inkonsekwent - tot lidmate beperk. Tog beveel die Kommissie aan - hy beskou sy poging dus nie as volmaak nie - dat die Algemene Sinodale Kommissie effektiewe metodes vind om in die nuwe Suid-Afrika sy openbare getuienis te lewer (NGK 1998:78).

Dat hierdie stuk van AKLAS oor die oorgang na 'n nuwe Suid-Afrika nog nie 'n voltooide, afgehandelde kerklike profesie is nie, blyk uit die aanvaarding van die aanbeveling deur die Algemene Sinode van 1998 dat dit as 'n gespreksdokument na gemeentes verwys word. Hierdie verwysing spruit moontlik ook uit die kerkskeuring op Kerk en Samelewing 1986. Omstrede kwessies moet wyer as die Algemene Sinode in die NG Kerk versprei word om die kans op konsensus te verhoog (NGK 1994:354-355).

Die Sinode verklaar die NG Kerk "uitsluitlik" 'n kerk van Christus wat omvattende koninkryksdiens in die gemeenskap lewer. Teenoor sy eie lidmate praat die Algemene Sinode profeties as hy hulle aanpor om hulle roeping te vervul waar die Here hulle plaas. Hulle sal 'n konstruktiewe rol in die nuwe samelewing speel as hulle hulle beywer vir die vestiging van Christelike lewenswaardes. Lidmate moet ook by diensaksies wat afgestem is op die behoeftes van die breë gemeenskap, betrokke raak. AKLAS moet die NG Kerk lei oor sy geloofsidentiteit en getuienis in die samelewing (NGK 1998:518).

Uit die inhoud van hierdie stuk van die Algemene Sinode van 1998 oor die oorgang in Suid-Afrika kan afgelei word dat dit vir NGK-gemeentes 'n stimulerende gespreksdokument moes wees. Die dokument wys op verskeie sake waaroor lidmate van die NG Kerk op daardie stadium ernstig gepraat het. Die feit dat sy profetiese kritiek op die oorgang tot NGKlidmate beperk is en dat hy swyg oor die impak en waardes van die eksterne probleme waarvoor hulle in die oorgang staan, verminder egter die waarde daarvan. Daar bestaan boonop geen aanduiding watter effek of invloed die stuk waar ook al gehad het nie.

Die vermoede bestaan dat die stuk as 'n profetiese getuienis in dieselfde liga hoewel op 'n laer vlak - as Kerk en Samelewing 1986 en 1990 kon beweeg. Dit het egter nie gebeur nie. Daarvoor is daar ten minste twee aantoonbare redes. Die eerste is die eensydige aanpak daarvan. Die stuk konsentreer 
op negatiewe NGK-lidmate en min op die ingewikkelde, vreemde situasie waarin hulle staan en hulle aangeduide lewensroeping moet nakom. Daar is nie sprake van JA Heyns, eventueel 'n kerklike profeet teen apartheid, se kritiese solidariteit om kerklik effektief te wees nie (Heyns 1977:98-108) ${ }^{5}$. In hierdie opsig maak die stuk hom skuldig aan die alledaagse retoriek van die, vir baie lidmate, vreemde nuwe Suid-Afrika. Die tweede is dat die dokument se ontstaansgeskiedenis verklap dat dit nie so ernstig as die stukke van 1986 en 1990 opgeneem is nie.

In 1999 verskyn die hele verslag as 'n artikel van DE de Villiers, 'n lid van AKLAS, in 'n akademiese tydskrif (De Villiers 1999:15-38; NGK 1998:89). Die stuk is dus nie 'n vrug van die besinning in die volle kommissie nie, maar 'n stuk wat - moontlik - van die kant af deur die kommissie aanvaar en aan die Algemene Sinode van 1998 voorgelê is. So sou dit nooit die beter produk van goeie spanwerk kon wees nie. Inteendeel, dit is die werk van profete wat die "preek" redelik haastig goedgekeur het. Die Algemene Sinode het die "dringende" saak wat in sy verloop geen dringendheid vertoon het nie, daarna daar gelaat.

Hierdie voetesleep oor die oorgang in die dekade na 1994 het nou 'n tendens by die Algemene Sinode as 'n profeet geword. Die NG Kerk wou die nuwe Suid-Afrika positief benader en 'n bydrae lewer - wat die NG Kerk betref het apartheid sy swanesang gesing en moes die nuwe land eenvoudig werk - maar iewers het twyfel en 'n gebrek aan geesdrif die dinamiek hiervan teruggehou. Die situasie is verswaar deur die NG Kerk se negatiewe ervaring van ander owerheidskwessies waarby die NG Kerk betrek is: die HOP, die herverdeling van grond en die wye voorkoms van korrupsie in die nuwe gemeenskap. Om hierdie twyfel te neutraliseer, sou die Algemene Sinode van 1998 in die teken van 'n stabilisering van gereformeerde waarhede staan (Strauss 2013:32vv). Hierdie stabilisering sou ook blyk uit 'n verslag oor die uitvoering van 'n ander opdrag deur AKLAS aan

5 JA Heyns was die voorsitter van die NG Kerk se Algemene Sinode van 1986 en die middelpunt van pogings wat met Kerk en Samelewing-1986 agterna die aanvaarbaarheid van die NG Kerk probeer bevorder het. Dit het aan hom die bynaam van "Meneer NG Kerk" besorg. By geleentheid en teenoor die trant van die verslag oor die oorgang in Suid-Afrika voor die Algemene Sinode van 1998, wys Heyns daarop daar'n ongelykheid onder die mense van Suid-Afrika voorkom, nie in menswees nie, maar in Westerse kulturele prestasie en geleenthede. 'n Ongelykheid wat tot beter 'n verstaan van die situasie en die oorgang kon lei, Williams 2006:278,327. 
die Sinode van 1998: kerk en staat in die huidige grondwetlike bedeling (NGK 1998:83). Kerk en staat in Suid-Afrika en die Kommissie se leiding aan lidmate oor die oorgang in Suid-Afrika, is uit mekaar gehou. Moontlik omdat die oorgang op eie lidmate en NG Kerkpraktyke afgestem was en die nuwe grondwetlike bedeling op die vasgelegde grondwet. 'n Beoordeling van die nuwe situasie is egter in al twee verslae as 'n noodsaaklike punt wat moes kom, aangedui.

\section{Kerk en staat}

Aan die begin van sy verslag oor "kerk en staat en die huidige grondwetlike bedeling", wys AKLAS op 'n versoek van die ASK dat hy aan die saak "aandag gee". Op daardie stadium was die tyd voor die Algemene Sinode van 1998 egter te kort om "diepgaande studie" te doen. Daarom wys AKLAS op die verskil in vertrekpunte van die teokratiese ideaal in die politiek soos die NG Kerk dit in die NGB se artikel 36 bely en die SuidAfrikaanse Grondwetlike bedeling na 1994 met sy demokrasie gebou op die Handves van Menseregte. Die antwoord op die verdere versoek dat AKLAS die beleid van die Suid-Afrikaanse Regering beoordeel soos wat Kerk en Samelewing 1986 en 1990 dit met apartheid gedoen het, word beperk tot enkele punte (NGK 1998:83).

Die Kommissie verklaar dat sy kritiese vrae oor kerk en staat in SuidAfrika nie spruit uit 'n geestelike hoogmoed of 'n nostalgie oor die vorige bedeling nie. Hy is dus bedag op so 'n reaksie uit die ANC Regering op die kritiek van die NG Kerk. Tog wys AKLAS daarop dat die konsep van menseregte nie alle politieke probleme oplos of 'n politieke heilsleer is nie. 'n Gevolg van die Handves is 'n toenemende pluralisme met teenstrydige waardestelsels in Suid-Afrika. Sulke verskynsels word van owerheidsweë geduld as dit nie buite die Grondwet om beweeg nie. Met sy hoë misdaaden korrupsiesyfer in alle sektore hier in 1998, moet die vraag egter gevra word of 'n humanistiese indiwidualisme soos gedra deur die Grondwet wenslik is vir Suid-Afrika? Is die "gom" van die gemeenskaplike verstaan van menseregte sterk genoeg om die gemeenskap bymekaar te hou? 'n Dringende gesprek oor die saambindende eenheidskrag van "godsdienstige waardes" moet plaasvind. Daarvoor sal die Suid-Afrikaanse Raad van Kerke die aangewese platform wees (NGK 2002:572). Die barmhartigheidsdiens 
van die NG Kerk moet in sy skakeling met die staat sy identiteit handhaaf en nie sy gehoorsaamheid aan Christus opoffer nie (NGK 1998:83-87).

Die aanbevelings van AKLAS word feitlik net so deur die Algemene Sinode van 1998 aanvaar. Hierdie aanbevelings word beperk tot die bevestiging van enkele belydeniswaarhede oor kerk en staat en aanvaarde kerklike begrippe oor die posisie van die kerk in die samelewing.

Volgens die Algemene Sinode van die NG Kerk van 1998 vier jaar na die oorgang en op voordrag van AKLAS, moet die owerheid die goeie bevorder en die kwade bestry. Gelowiges as lojale landsburgers moenie hulle gehoorsaamheid aan God in die gedrang bring of kompromitteer nie. Gelowiges is vreemdelinge in die sondige wêreld, maar ook burgers in God se omvattende koninkryk wie se naastediens dit wat normaalweg van landsburgers gevra word, moet oortref. Daarvoor moet hulle seker wees van hulle identiteit in Christus. Gemeentes moet hieroor besin en in ootmoed erken dat die huidige situasie 'n geleentheid van die Here is om God en sy koninkryk volgens sy wil te dien (NGK 1998:519).

Hiermee sou die Algemene Sinode van 1998 voortgaan om meer innerlikkerklike waarhede en nie profetiese kritiek in die Suid-Afrikaanse situasie as geheel nie, te laat hoor. Die Sinode sou dus nie die nuusvoorblaaie haal nie. Sy profetiese uitsprake in 'n onsekere nuwe situasie wou aan lidmate toon dat samelewingsomvattende koninkryksdiens - met hart, mond en hand - 'n roeping bly en sin gee aan hulle bestaan in die land. Hoewel die nuwe situasie nie profeties-krities ontleed word nie, het hierdie Bybelse roeping geensins sy aktualiteit verloor nie. Inteendeel, die Algemene Sinode van 1998 doen 'n oproep dat gemeentes die implikasies van hierdie verslag bestudeer en besin oor die "betekenis van die vreemdelingskap van die kerk binne ons situasie ...” (NGK 1998:519).

Die Sinode wat die algemene standpunte van die NG Kerk hanteer, aanvaar dus dat die mondige lidmate in gemeentes dié roeping vir hulle eie situasie vertaal en praktiese gestalte daaraan gee. Gemeentes - dit bely die NG Kerk in NGB artikel 29 - vorm immers die kern van die kerk rondom die suiwer Bybelse bediening van die Woord, die Skriftuurlike gebruik van die sakramente en die handhawing van die kerklike tug (NG Kerk-Uitgewers 1982:29). In sy profetiese uitsprake na buite het hierdie boodskap skynbaar sonder groot bespreking stilweg sonder groot effek in gemeentes aangekom. 
Die blote feit dat die Algemene Sinode opnuut die vreemdelingskap van die gelowiges in die sondige wêreld, hulle roeping tot omvattende koninkryksdiens en 'n Christelike identiteit beklemtoon, staan sentraal en rigtinggewend in die situasie van 1998 in Suid-Afrika. Dit op sigself verraai reeds iets van die NG Kerk se beoordeling van die nuwe, vreemde gemeenskap waarin hy bestaan, maar dui ook aan dat hierdie vertrekpunte "basies" bly na die oorgang van 1994 in Suid-Afrika. Die profetiese gesag en die waarde van hierdie benadering mag deur hulle wat dit hoor, vergeet word omdat dit nie dramaties nuut en anders - soos die nuwe Suid-Afrika self - vir alle lidmate is nie. Die eenvoudige profetiese les van die Algemene Sinode van 1998 is egter dat 'n nuwe situasie nie 'n nuwe Bybel as lewensgids vir kerk en samelewing vra nie.

Ander sake in Suid-Afrika na 1994 kruis die geloofs- of kerklike belang van die NG Kerk buite sy eie inisiatief om: die HOP, die herverdeling van grond, die voorkoms van korrupsie in alle sektore van die gemeenskap én misdaad wat welig tier... Regeringsinisiatief plaas die eerste twee op die tafel van die Algemene Sinode, terwyl die wye openbare bekendheid van misdaad en korrupsie meebring dat die NG Kerk as 'n kerk betrokke by sy omgewing, dit nie kan ontwyk nie. Daarby toon sy hantering hiervan die begeerte by die NG Kerk om as kerk deur sy strukture koninkryksdiens in sy omgewing te verrig.

\section{Ander sake}

Tydens die Algemene Sinode van 11-20 Oktober 1994 is die Suid-Afrikaanse Regering se HOP nog in 'n proses van aanvaarding deur die parlement. 'n Witskrif waarin kommentaar op die plan gelewer word en waartoe die NG Kerk genooi word om sy insette te lewer, is egter reeds by die Sinode. Die NG Kerk wou aan die HOP deelneem deur sy Algemene Kommissie vir Diens van Barmhartigheid (AKDB). Behalwe vir kommentaar op die witskrif, moes die AKDB met die Regering in gesprek tree oor die HOP en die implementering daarvan soos in die witskrif gevisualiseer (NGK 1994:575). Hierdie reaksie reflekteer die versigtige, afwagtende optimisme van die Algemene Sinode in die nuwe staatkundige bedeling.

Tydens die historiese besoek van president Nelson Mandela op 13 Oktober aan die Algemene Sinode, reageer die vergadering met 'n onbestrede mosie 
waarin hy sy houding oor die nuwe staatkundige bedeling in Suid-Afrika, goed saamvat. Die Sinode se gebed is dat die nuwe Regering die land tot eer van God en tot voordeel van "al ons mense" sal regeer, dat daar 'n "radikale verbetering van die lewensomstandighede en toekomsgeleenthede van mense wat vir baie jare soveel moes ontbeer" sal wees en dat die NG Kerk die HOP "deeglik" sal bestudeer - hy neem die owerheid ernstig op - en "spoedig" sal aandui waar hy 'n bydrae kan lewer (NGK 1994:443). In 'n afsonderlike besluit oor die HOP beaam die Algemene Sinode: Suid-Afrika het 'n HOP nodig en die NG Kerk sal waar dit vir hom moontlik is, daaraan meewerk (NGK 1994:575). Oor hierdie samewerking is die vergadering so positief dat hy ook, soos in die verlede, vir afskrifte van die witskrif in Afrikaans vra (NGK 1994:575)!

Later rapporteer die AKDB aan die Algemene Sinode van 1998 dat die oë van die HOP "mettertyd" stilweg gesluit is (NGK 1998:196).

Die Algemene Sinode van 1994 gee aan sy ASK opdrag om, indien nodig, in oorleg met AKLAS “die vraagstuk" oor die herverdeling van grond te "hanteer" (NGK 1994:574). Dit word egter 'n komplekse saak met kerkliketiese kante wat vier en twintig jaar later steeds op die agenda van die regering is. Omdat daar in 1994-1998 vanaf die kant van die NG Kerk geen vordering is nie, verwys die Algemene Sinode van 1998 die saak na AKLAS om "verder" te bestudeer en, desnoods in oorleg met die ASK, na bevinding van sake te handel (NGK 1998:418). Die herverdeling van grond word dus soos 'n warm patat heen en weer tussen twee kommissies geslinger. Die saak moes egter tot 'n resultaat lei ...

Die gevolg is 'n deeglike, feite en profeties-etiese verslag (vgl NGK 2002:219) wat voor die Algemene Sinode van 2002 dien. Die verslag wys op diskriminerende wetgewing wat na Junie 1913 veroorsaak het dat die "voorheen benadeelde groepe" van hulle grond ontneem is. Die huidige Regering het in 1996 met 'n grondhervormingsprogram begin wat grond herverdeel en 'n sekerheid van verblyf wil vestig. Eise vir die teruggee of vergoeding van grond moes voor 31 Desember 1998 in wees en 67,531 sulke eise is sedertdien hanteer. AKLAS wys ook op verskillende metodes van grondonteiening, die feite van die besit en afgehandelde verdeling van grond - ook die grond van kerke - in Suid-Afrika en (NGK) kerklike riglyne vir "grondhervorming" (NGK 2002:219-225). 
Dit is opmerklik dat AKLAS kerklik-reformatories praat van "grondhervorming". Daarmee dui hy aan dat dit in Suid-Afrika nie om 'n rewolusionêre omkeer van grondbesit met sy chaotiese ekonomiese en juridiese gevolge moet gaan nie, maar 'n behoorlik geweegde, stelselmatige herverdeling. Dit is nie 'n blindelingse transformasie met ras as kriterium nie, maar 'n verdeling wat hom binne die raamwerk van versoening en die beginsels van die vrye markstelsel voltrek. In sy riglyne vra AKLAS 'n sensitiewe, nugtere aanpak, 'n gesonde landbou-ekonomiese (ook markverwante) en juridiese (billikheid na alle kante toe) basis, grondhervorming binne 'n omvattende ontwikkelingsprogram en 'n saak wat so gou moontlik afgehandel moet wees.

Die Algemene Sinode van 2002 aanvaar die verslag as riglyn vir sy voortgaande gesprek oor die saak in Suid-Afrika. Die vergadering besluit ook om die riglyne as die "profetiese stem van die Kerk" aan die owerhede en georganiseerde landbou in Suid-Afrika, Namibië en Zimbabwe deur te stuur. Die ASK moet onmiddellik in gesprek tree met die Suid-Afrikaanse regering oor die saak. Lidmate word ook versoek om sensitief te wees vir huisvesting vir hawelose mense. Die NG Kerk, lidmate en gemeentes kan met hierdie verslag in die hand 'n bemiddelende rol in die saak in die land speel (NGK 2002:549-550). Dat die verslag 'n relevante aar van die saak rakgeboor het, blyk later - in 2018 - uit die verskynsel dat die ekonomiese gevolge en die noodsaak van voedselvoorsiening en produksie na die verdeling van grond, van owerheidskant in Suid-Afrika erken word. Die begronde en realistiese profetiese stem van die NG Kerk in hierdie saak oorleef sy tyd van ontstaan.

In 2002 is die Algemene Sinode dankbaar vir min of meer 'n soortgelyke beleid by die Suid-Afrikaanse Regering (NGK 2002:549).

Ten opsigte van korrupsie en misdaad in Suid-Afrika skerp die Algemene Sinode van 2002 lidmate en gemeentes op om hierdie verskynsel te bestry en deur hulle normale kerklike bediening 'n teenkultuur te kweek. Gemeentes moet polisiekantore aanneem en geestelik en moreel ondersteun (NGK 2002:550). Daarby moet NGK-gemeentes oopmaak vir mense met trauma rondom plaasmoorde en die ASK in kontak met georganiseerde landbou bly (NGK 2002:568). Reeds in 1998 doen die Algemene Sinode 'n beroep op die Suid-Afrikaanse owerheid om "met alle mag tot sy beskikking" 
misdaad te voorkom. Lidmate moet ook die inisiatief neem om misdaad in hulle omgewing te voorkom en te bestry (NGK 1998:419).

\section{Die NG Kerk: 'n profeet in sy eie land?}

Dit is duidelik dat die Algemene Sinode van die NG Kerk in die dekade na 1994 by geleentheid sy profetiese stem gebruik om die Suid-Afrikaanse owerheid aan te spreek. In die proses is NGKO artikel 21 nie bewustelik op die tafel nie, maar werk die Algemene Sinode tog vanuit die beginsel en koers wat daaruit spruit.

In die profetiese aanspreek van sy staatsowerheid word die Algemene Sinode deur twee faktore gerem: die eerste een is die lewensbeskoulik-vreemde omgewing van waaruit die owerheid opereer - vreemd vir die NG Kerk wat deur sy Algemene Sinode as 'n gereformeerde kerk beskou word (NGK 2007H:89) - wat meebring dat die NG Kerk soms na gemeenskaplike grond in sy uitsprake moet soek om as kerk met die owerheid te kommunikeer. 'n Gemeenskaplike lewensbeskoulike basis tussen kerk en owerheid ontbreek en bring mee dat hulle nie vanuit dieselfde hoek na sake kyk nie. Hulle is nie geesgenote of karperde, elkeen vanuit sy eie aard en op sy terrein, nie en sal mekaar nie noodwendig oor dieselfde saak in die gemeenskap aanvul of kerklik en staatlik komplementeer nie. Tensy hulle mekaar op sekere sake in die Akte van Menseregte soos in die Suid-Afrikaanse Grondwet, vind: sake soos die vryheid van godsdiens, assosiasie en spraak (vgl benadering by Vorster 2003; Strauss 2010b: 327; NGKO 2013:1).

Die tweede faktor is die skynbare versigtigheid en lusteloosheid wat die NG Kerk se profetiese stem direk na 1994 kenmerk. Die verwagte profetieskritiese ontleding van die politieke bedeling in Suid-Afrika na 1994 waarin die liberaal-demokratiese, humanistiese onderbou en vreemde praktyke - vir 'n Christen as 'n vreemdeling in die sondige wêreld (vgl Algemene Sinode van 1998) - aangespreek word, ontbreek nog. Daar is ook geen tasbare effek uit regeringsoptrede wat 'n aanduiding daarvan is dat die NG Kerk gehoor én positief opgeneem word nie. Welwillendheid bestaan, maar dit bly beperk tot ongereelde kontak deur kommissies en hulp aan byvoorbeeld bestaande projekte van die NG Kerk se Diens van Barmhartigheid (NGK 2002:22,27) In die NG Kerk leef daar hieroor 'n 
versigtigheid wat verlammend en versmorend inwerk en 'n nuwe Kerk en Samelewing in 'n nuwe samelewing verhoed.

Vanuit sy gereformeerde hoek moet die beklemtoning deur die Algemene Sinode van die outentieke lewenstyl van die gelowiges as hulle roeping in Suid-Afrika én die noodsaak van'n kerklik-profetiese stem van die NG Kerk onderstreep word. Die nie-dramatiese waarheid hiervan kan meebring dat dit aan lidmate verbygaan. Tog moet hierdie roeping die kern van die NG Kerk se profetiese boodskap na die gemeenskap wees, ook vandag.

Moontlik kan die geldigheid van hierdie kritiek beskou word as die gevolg van 'n profeet wat nie in sy eie land geëer word nie. Dit is egter nie ongekwalifiseerd waar nie. Die waardering is daar. So ook die gebruik van die Woord van God as die kerklike bron vir egte profesie op algemene sinodale vlak.

\section{Bibliografie}

Biesterveld, P. en Kuyper, H.H. 1905. Kerkelijk Handboekje. Kampen: Bos.

Botes, D.H. 2012. Die NG Kerk as profeet teenoor die Suid-Afrikaanse Regering 1962-2002. 'n Kerkhistoriese perspektief. Bloemfontein:UV. Ongepubliseer.

Bouwman, H. 1985. Gereformeerd Kerkrecht II. Kampen: Kok (3 ${ }^{\mathrm{e}}$ onveranderde druk).

De Villiers, D.E. 1999. Die NG Kerk en die oorgang na 'n nuwe SuidAfrika. Skrif en Kerk 20/1, 15-38.

Fowler, S. 1988. The state in the light of the Scriptures. Potchefstroom: PU for CHE.

Heyns, J.A. 1977. Die kerk. Pretoria: NG Kerkboekhandel 1988.

Hommes, N.J. sa. God en Keizer in het Nieuwe Testament. Franeker: Wever.

Jansen, J. 1952. Korte verklaring van de Kerkorde van de Gereformeerde

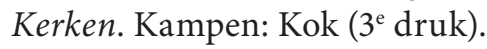


Kleyn, D. en Viljoen, F. 1999. Beginnersgids vir regstudente. Kenwyn: Juta ( $2^{\mathrm{e}}$ druk).

Kock, P. de B. 1975. Christelike Wysbegeerte. Inleiding. Bloemfontein: Sacum.

Kuitert, H. 1988. Alles is politiek maar politiek is niet alles. Baarn: Ten Have (5 druk).

Nauta, D. 1971. Verklaring van de Kerkorde van die Gereformeerde Kerken in Nederland. Kampen: Kok.

Nederduitse Gereformeerde Kerk (NGK) 1994, 1998, 2002, $2007 \mathrm{H}$. Handelinge van die Algemene Sinode. Sl:sn.

NG Kerkorde (NGKO) 1964. Kerkorde van die NG Kerk 1962. Kaapstad: NG Kerk-Uitgewers.

NG Kerkorde (NGKO) 1994, 1998, 2002, 2013. Die Kerkorde. Sl:sn.

NG Kerk-Uitgewers 1982. Ons glo... Kaapstad: NG Kerk-Uitgewers.

Polman, A.D.R. sa. Onze Nederlandsche Geloofsbelijdenis IV. Franeker: Wever.

Sizoo, A. sa. Johannes Calvijn Institutie III. Delft: Meinema (6 $6^{\mathrm{e}}$ druk).

Spoelstra, B. 1989. Gereformeerde Kerkreg en kerkregering. Hammanskraal: HTS.

Stone, H. 2014. Weerskant die Rubicon. Brandfort: FAK.

Strauss, P.J. 1994. Kerklike sake, die kerk en die koninkryk van God. In die Skriflig 28/4, 581-592.

Strauss, P.J. 2010a. Kerk en orde vandag. Met die klem op die NG Kerk. Bloemfontein: SunMedia.

Strauss, P.J. 2010b. Uitgangspunte vir staatsoptrede in die Institusie van Calvyn soos vergelyk met uitgangspunte van Suid-Afrika se Handves van Regte (1996). In die Skriflig 44/2, 317-331.

Strauss, P.J. 2013. Kerkwees in die branding. Die NG Kerk in algemene sinodale verband 1994-2011. Bloemfontein: SunMedia. 
Vorster, N. 2003. Kerk en menseregte binne 'n regstaat. Potchefstroom: Potchefstroom Teologiese Publikasies.

Williams, H.H. 2006. JA Heyns en die Ned Geref Kerk en apartheid. Bloemfontein: UV. Ongepubliseer. 